\title{
Plankton studies in Buzzards Bay, Massachusetts, USA. I. Hydrography and bacterioplankton, 1987 to 1990
}

\author{
Jefferson T. Turner, David G. Borkman*
}

Center for Marine Science and Technology, University of Massachusetts, Dartmouth, North Dartmouth, Massachusetts 02747, USA

\begin{abstract}
The hydrography, water chemistry and plankton communities of Buzzards Bay, Massachusetts, USA, a temperate estuary $\left(41^{\circ} \mathrm{N}\right.$ ), were studied over 45 cruises (10 October 1987 to 11 September 1990). Surface temperature varied from -2.0 to $27.26^{\circ} \mathrm{C}(\mathrm{n}=360)$, but because of shallow depth (mean $=10 \mathrm{~m}$ ), strong wind and tidal mixing, the water column was isothermal most of the year. The only thermal structure was found during the summer, when it was minimal and appeared to be a diel phenomenon, partly related to solar heating. Secchi disk readings ranged from 0.75 to $9.0 \mathrm{~m}$ $(\mathrm{n}=352)$. Due to shallow depth most of the water column was in the euphotic zone $(>1 \%$ of surface illumination) for most of the year Exceptions were bay-wide levels of only 60 to $80 \%$ of the water column being euphotic during each of 3 winters, as well as at the sewage outfall of the City of New Bedford throughout 3 years where regardless of season only 40 to $80 \%$ of the water column was euphotic due to light attenuation by fine particles of sewage sludge. Surface bacterioplankton abundance ranged from 0.30 to $10.92 \times 10^{6}$ cells $\mathrm{ml}^{-1}(\mathrm{n}=352)$, and fluctuations generally tracked those of temperature. The overwhelmingly dominant aspect of the water-column ecology of Buzzards Bay is high variability due to severe seasonality of physical parameters, particularly temperature.
\end{abstract}

\section{INTRODUCTION}

Estuaries are variable habitats. Their water masses and populations exhibit natural fluctuations on time scales ranging from tidal cycle to daily to seasonal to interannual. Superimposed over this natural variability are anthropogenic influences that can change both temporally and spatially. This is particularly true for estuaries that are partially urbanized. Attempts to manage such systems can be hampered by lack of baseline ecological data, and inability to separate natural from human-induced variability. It is often difficult to recognize 'abnormal' because we do not appreciate the variability that is 'normal'. Buzzards Bay, Massachusetts (see Fig, 1), is such an estuary.

Information on the ecology of Buzzards Bay is surprisingly limited. This is despite the fact that studies in the bay date back almost a century (Peck 1896,

- Present address: Graduate School of Oceanography, University of Rhode Island, Narragansett, Rhode Island 02882, USA.
Sumner et al. 1913, Fish 1925, Lillick 1937). There have been major studies of benthic communities (Sanders 1958, 1960, Wieser 1960, Rhoads \& Young 1970, Young 1971, Rhoads et al. 1975), as well as examination of the effects of tidal resuspension on the water column (Roman 1978, 1980, Roman \& Tenore 1978). However, other studies of pelagic communities of Buzzards Bay are limited. Aside from 2 mo of samples for phytoplankton at a single station in Buzzards Bay (Lillick 1937), and Anraku's (1964) survey of adult copepods in relation to the Cape Cod Canal, the plankton and most other aspects of the water-column ecology of Buzzards Bay have been virtually unstudied. Recent publications on plankton have been specialized, dealing with meroplankton only (Butman 1989) or benthic resting eggs of a single species of planktonic copepod (Marcus 1984, Marcus \& Fuller 1989). It seems that the water column of Buzzards Bay has historically been viewed from the benthos up rather than from the surface down. 
There has been a recent resurgence of interest in Buzzards Bay, partly due to concerns about pollution. Sediments in New Bedford Harbor contain large amounts and complex mixtures of toxic compounds (Pruell et al. 1990), long-term effects of an oil spill are still apparent (Sanders et al 1980), and 'cultural eutrophication' of Buzzards Bay embayments is proceeding (Valiela \& Costa 1988). Buzzards Bay has been classified by NOAA/EPA (1989) as highly susceptible to concentrating particulate and dissolved pollutants due to large overall estuarine volume relative to comparatively low volume of freshwater inflow that would flush the estuary. Although bay-wide nitrogen loading is relatively low, specific sites such as the New Bedford sewage outfall exhibit substantial eutrophication effects (Smayda 1989). Although information on specific, usually polluted, subsections of the bay continues to accumulate in reports to regulatory agencies and student theses, information on such basic parameters as inorganic nutrient distributions has lacked sufficient temporal and spatial coverage to quantify trends (Stenner et al. 1988), particularly for the open waters of the bay.

Beginning in October, 1987, with support from the Massachusetts Department of Environmental Protection, an extensive study of hydrography, water chemistry and plankton in Buzzards Bay was begun. Temperature, salinity, light penetration, nutrients (ammonium, nitrate, nitrite, orthophosphate, silicate), chlorophyll a and phaeopigments, bacterioplankton, phytoplankton, microzooplankton, net-zooplankton, and ichthyoplankton were synoptically sampled. Data on hydrography, light penetration and bacterioplankton for the first 3 yr (October 1987 to September 1990) are presented here, and Borkman \& Turner (1993; companion article) address nutrients, chlorophyll $a$ and phaeopigments for the same period.

\section{METHODS}

Stations. Samples were collected at 8 stations throughout Buzzards Bay (Fig. 1). Three of these (Stns $4,5 \& 6$ ) were at buoys along the central axis of the bay at depths of 10 to $15 \mathrm{~m}$. Stn 2 (depth $=8$ to $12 \mathrm{~m}$ ) was at the southwestern end of the Cape Cod Canal. At this station there are strong tidal currents (up to 4 knots) which change direction every $6 \mathrm{~h}$. Thus, hydrographic conditions and plankton populations at Stn 2 are frequently different from those of the rest of Buzzards Bay since these water masses originate north of Cape Cod, which is considered to be a major biogeographic boundary (Ekman 1953). In order to complete sampling of the entire bay in $1 \mathrm{~d}$, all stations were sampled upon arrival irrespective of the state of the tide. Stns 1 \& 3 were in the shallow embayments of Mattapoisett and Megansett Harbors at depths of 5 to $8 \mathrm{~m}$. Stn 7 (depth $=6$ to $8 \mathrm{~m}$ ) was over the subsurface outfall of the primary treatment sewage plant of New Bedford. Stn 8 (depth $=8 \mathrm{~m}$ ) was in the main channel of the inner harbor of New Bedford. This harbor is almost completely enclosed by a stone hurricane dike; thus circulation is restricted relative to the rest of the bay (Signell 1987, Geyer \& Dragos 1990). All stations were precisely located by Loran coordinates. Water column depths at a given station varied with tidal range, which in Buzzards Bay ranges from approximately 1.0 to $1.5 \mathrm{~m}$.

Sampling. Samples were collected at all 8 stations on each of 45 cruises between 1 October 1987 and 11 September 1990 (Table 1). All stations were sampled in a single day on each cruise. Cruises were monthly except for biweekly cruises in October 1987 , June to October 1988, and June to August 1989.

At each station temperature was measured to the nearest $0.01^{\circ} \mathrm{C}$ with a Beckman temperature probe at $1 \mathrm{~m}$ intervals over the entire water column. Water transparency was measured with a $30 \mathrm{~cm}$ diameter

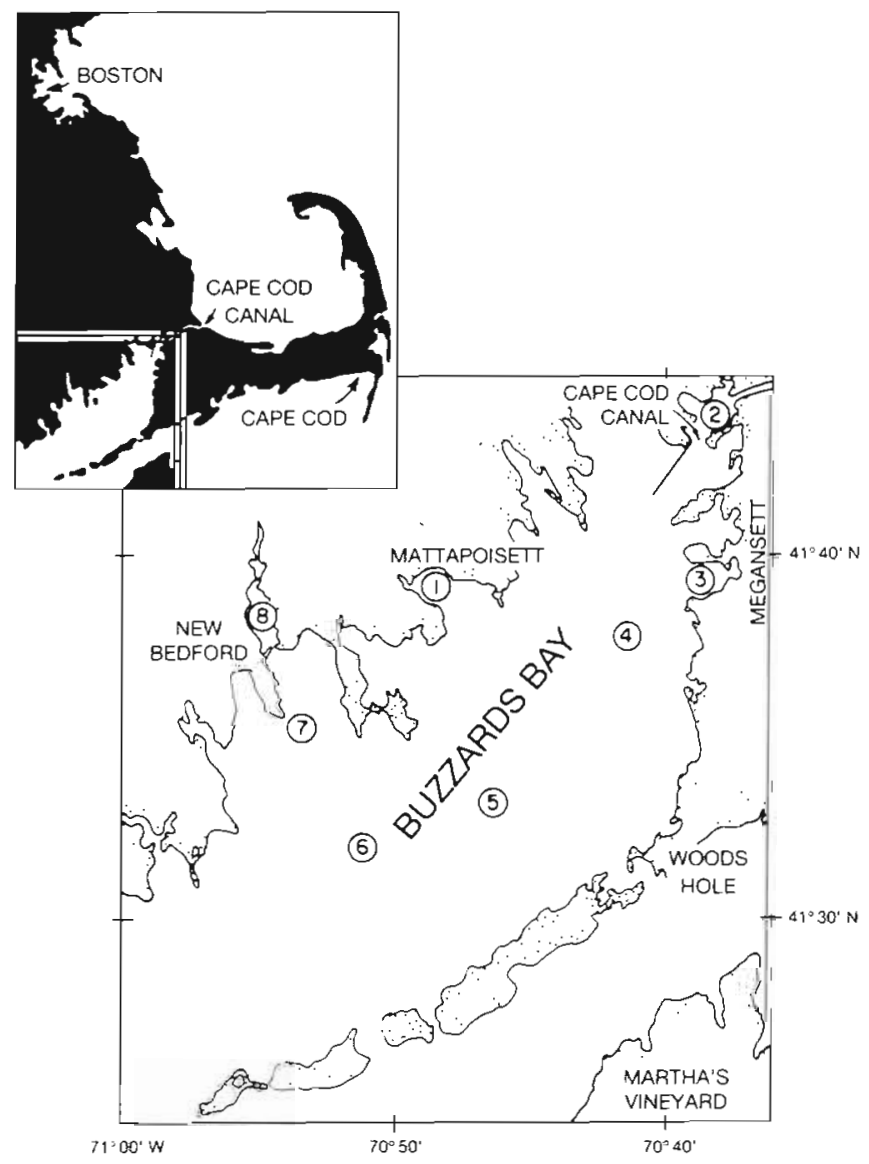

Fig. 1. Locations of sampling stations in Buzzards Bay 
Table 1. Cruise numbers, dates, and Julian days of sampling

\begin{tabular}{|c|c|c|c|}
\hline Cruise & & Date & Julian day \\
\hline 1 & 1 & Oct 1987 & 274 \\
\hline 2 & 20 & Oct 1987 & 293 \\
\hline 3 & 24 & Nov 1987 & 328 \\
\hline 4 & 16 & Dec 1987 & 350 \\
\hline 5 & 8 & Jan 1988 & 8 \\
\hline 6 & 2 & Feb 1988 & 33 \\
\hline 7 & 1 & Mar 1988 & 61 \\
\hline 8 & 5 & Aрг 1988 & 96 \\
\hline 9 & 3 & May 1988 & 124 \\
\hline 10 & 7 & Jun 1988 & 159 \\
\hline 11 & 21 & Jun 1988 & 173 \\
\hline 12 & 13 & Jul 1988 & 195 \\
\hline 13 & 27 & Jul 1988 & 209 \\
\hline 14 & 10 & Aug 1988 & 222 \\
\hline 15 & 23 & Aug 1988 & 235 \\
\hline 16 & 6 & Sep 1988 & 249 \\
\hline 17 & 20 & Sep 1988 & 263 \\
\hline 18 & 4 & Oct 1988 & 277 \\
\hline 19 & 18 & Oct 1988 & 291 \\
\hline 20 & 8 & Nov 1988 & 312 \\
\hline 21 & 6 & Dec 1988 & 340 \\
\hline 22 & 3 & Jan 1989 & 3 \\
\hline 23 & 7 & Feb 1989 & 38 \\
\hline 24 & 9 & Mar 1989 & 68 \\
\hline 25 & 4 & Apr 1989 & 94 \\
\hline 26 & 2 & May 1989 & 122 \\
\hline 27 & 6 & Jun 1989 & 157 \\
\hline 28 & 27 & Jun 1989 & 178 \\
\hline 29 & 6 & Jul 1989 & 187 \\
\hline 30 & 18 & Jul 1989 & 199 \\
\hline 31 & 1 & Aug 1989 & 213 \\
\hline 32 & 17 & Aug 1989 & 229 \\
\hline 33 & 13 & Sep 1989 & 256 \\
\hline 34 & 11 & Oct 1989 & 284 \\
\hline 35 & 8 & Nov 1989 & 312 \\
\hline 36 & 6 & Dec 1989 & 340 \\
\hline 37 & 3 & Jan 1990 & 3 \\
\hline 38 & 27 & Feb 1990 & 58 \\
\hline 39 & 20 & Mar 1990 & 78 \\
\hline 40 & 3 & Apr 1990 & 93 \\
\hline 41 & 1 & May 1990 & 121 \\
\hline 42 & 26 & Jun 1990 & 177 \\
\hline 43 & 20 & Jul 1990 & 201 \\
\hline 44 & 21 & Aug 1990 & 233 \\
\hline 45 & 11 & Sep 1990 & 254 \\
\hline
\end{tabular}

white Secchi disk, with estimates to the nearest half meter. Water samples were collected with Niskin bottles from surface, mid-depth, and near-bottom depths. These samples were used for synoptic salinity, nutrient, chlorophyll a and phaeopigment, phytoplankton, microplankton, and (surface only) bacterioplankton data. Following each Niskin cast a vertical zooplankton net tow was made at each station. Salinity was measured (to the nearest \%a) with a refractometer. Data on temperature, salinity, light penetration, and bacterioplankton are presented here.
Light penetration. The $1 \%$ isolume depth (i.e. bottom of the euphotic zone) was calculated from Secchi disk measurements by:

$$
\text { Isolume depth }(\mathrm{m})=\frac{\ln (\text { fraction of light) }}{-K}
$$

where fraction of light is percent of that at the surface (i.e. 0.01 for $1 \%$ ), and $K$ (extinction coefficient) $=$ 1.44/Secchi depth (in meters).

Bacterioplankton. Bacterioplankton samples were collected from the surface only, beginning with Cruise 2. Aboard ship $18 \mathrm{ml}$ of surface water was preserved with $2 \mathrm{ml}$ of $12 \% 0.2 \mu \mathrm{m}$ filtered gluteraldehyde solution, for a final concentration of $0.6 \%$ gluteraldehyde. Samples were kept refrigerated until epifluorescence microscopic analyses, usually within 1 to $2 \mathrm{~d}$ after each cruise.

Cells were concentrated by filtration of $5 \mathrm{ml}$ subsamples onto $0.2 \mu \mathrm{m}$ pore black Nucleopore filters, and stained with DAPI (Porter \& Feig 1980). Filters were sandwiched between coverslips and slides with non-fluorescing immersion oil. Bacterioplankton cells were counted at $1000 \times$ with oil immersion using on Olympus BH-2 epifluorescence microscope equipped with an ocular Whipple disk. At least 400 cells were counted, giving a counting accuracy of better than $\pm 10 \%$ (Guillard 1973). Knowing the dimensions of each Whipple disk field and the total filtration area containing cells, it was possible to calculate the fraction of the total sample that had been counted. Since samples from Stn 7 (the New Bedford sewage outfall) always contained large numbers of rods, whereas elsewhere the bacterioplankton was almost exclusively composed of small cocci $<1 \mu \mathrm{m}$ in diameter, the percentages of total cells that were rods were counted at $\operatorname{Stn} 7$.

We did not separate photosynthetic versus nonphotosynthetic protists (Caron 1983), but obtained counts of microflagellates in phase-contrast analyses of phytoplankton samples preserved in Utermöhl's solution (Guillard 1973) that were concentrated by sedimentation rather than filtration.

\section{RESULTS}

\section{Temperature}

There was pronounced seasonality of surface temperature (range $=-2.0$ to $27.26^{\circ} \mathrm{C}$, mean $=12.94{ }^{\circ} \mathrm{C}$, $\mathrm{n}=360$ ) each of the $3 \mathrm{yr}$ of the study (Fig. 2). Due to strong wind and tidal mixing, the water column was usually isothermal with $<1^{\circ} \mathrm{C}$ variation between the surface and bottom, except during the summer. Even then, surface warming appeared to be partly a diel 


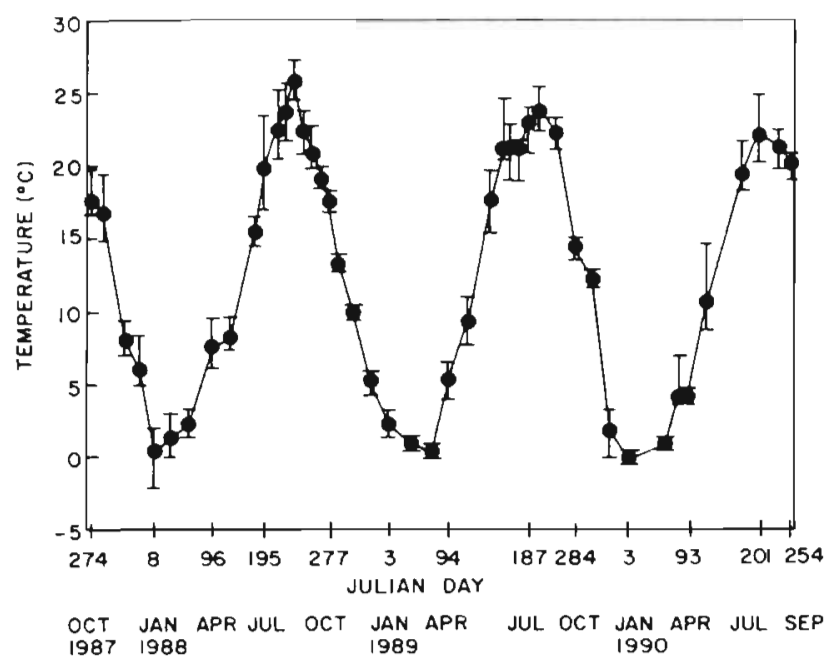

Fig. 2. Mean bay-wide surface temperatures. Vertical bars represent ranges at 8 stations on each sampling date $(n=360)$

phenomenon, probably due to insolation (see Fig. 3 for 1988 data). Similar patterns occurred in the summers of 1989 and 1990 . The only times having $>1.0^{\circ} \mathrm{C}$ vertical departure in temperature for a given station were June to August 1988, June to September 1989, and May to August 1990.

\section{Salinity}

Salinity was almost uniformly $30 \%$ throughout the bay at virtually all times (range $=26$ to $31 \%, n=1080$ ). The only times when salinities were low were at $\operatorname{Stn} 8$, in the enclosed inner harbor of New Bedford, immediately after or during heavy rain.

\section{Light penetration}

Buzzards Bay water is usually visibly green, so Secchi disk values were low (range $=0.75$ to $9.0 \mathrm{~m}$, mean $=3.72 \mathrm{~m}, \mathrm{n}=352$; no data for Cruise 1 ). However, at $\operatorname{Stn} 7$ over the sewage outfall, water color was usually brown due to fine particles of sludge. Secchi disk values at this station were 0.75 to $5.0 \mathrm{~m}$, with a mean of $1.85 \mathrm{~m}$. Excluding Secchi disk data from Stn 7 increases the bay-wide average from 3.72 to $3.99 \mathrm{~m}$.

Despite the low Secchi disk values, since Buzzards Bay is shallow (mean depth $=10 \mathrm{~m}$ ), most of the water column is in the euphotic zone most of the time (Fig. 4). Exceptions were generally in winter, when most stations had only 60 to $80 \%$ of the water column with $>1 \%$ of surface light, or most of the time at $\operatorname{Stn} 7$, when only 40 to $80 \%$ of the water column was euphotic (Fig. 4).

\section{Bacterioplankton}

Surface bacterioplankton numbers exhibited a wide range $\left(0.30\right.$ to $10.92 \times 10^{6}$ cells $\mathrm{ml}^{-1}$, mean $=2.96 \times 10^{6}$, $\mathrm{n}=352$ ), with pronounced seasonal fluctuation (Fig. 5). Numbers were generally high in summer and low in winter, and although there was generally a direct relationship between bacterioplankton abundance and temperature (Fig. 6), the regression was not significant. This was, in part, due to high inter-station variability. Bacterioplankton abundance was generally higher at Stn 7 (sewage outfall) and Stn 8 (New Bedford inner harbor) than elsewhere.

The bacterioplankton assemblage was almost exclusively comprised of small cocci $<1 \mu \mathrm{m}$ in diameter, except at Stn 7. There, rod-shaped cells $>2 \mu \mathrm{m}$ in length were always abundant, comprising up to $72 \%$, and a mean of $30 \%$, of total bacterioplankton cells. Since such an abundance of rods was not encountered elsewhere, we suspect that these were fecal coliforms or other sewage-related bacteria.

Relationships between abundance of bacterioplankton and potentially bacterivorous microflagellates are of interest. However, these can only be explored for the first year of sampling since microflagellate counts are only complete for Cruises 2 to 17 . These data reveal that both bacterioplankton and microflagellates were most abundant during summer (Fig. 7).

\section{DISCUSSION}

The overwhelming aspect of the water-column ecology of Buzzards Bay is variability. In part this is due to severe seasonality, but also due to short-term meteorological or tidal forcing

The seasonal temperature signal is dramatic, spanning nearly $30^{\circ} \mathrm{C}$ (Fig. 2). Due to strong wind and tidal mixing (Signell 1987, Geyer \& Dragos 1990), the water column is generally isothermal, as also noted by Rhoads et al. (1975) and Roman \& Tenore (1978).

Insolation is seasonally variable, as would be expected at $41^{\circ} \mathrm{N}$ latitude, but due to shallow depths, most of the water column is in the euphotic zone for most of the year (Fig. 4). The only exceptions were throughout the bay in December and January, and throughout the year over the New Bedford sewage outfall.

Bacterioplankton abundance fluctuated considerably with season, but generally within the order-ofmagnitude range of $10^{6}$ cells ml-1 (Fig. 5). Abundance was somewhat higher at the more eutrophic New Bedford Harbor stations ( $7 \& 8$ ), but not dramatically so (Fig. 5). Rather, the most apparent relationship was between bacterioplankton abundance and seasonality of temperature (Figs. $5 \& 6$ ). Similar results have been 

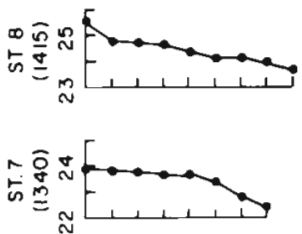

兽
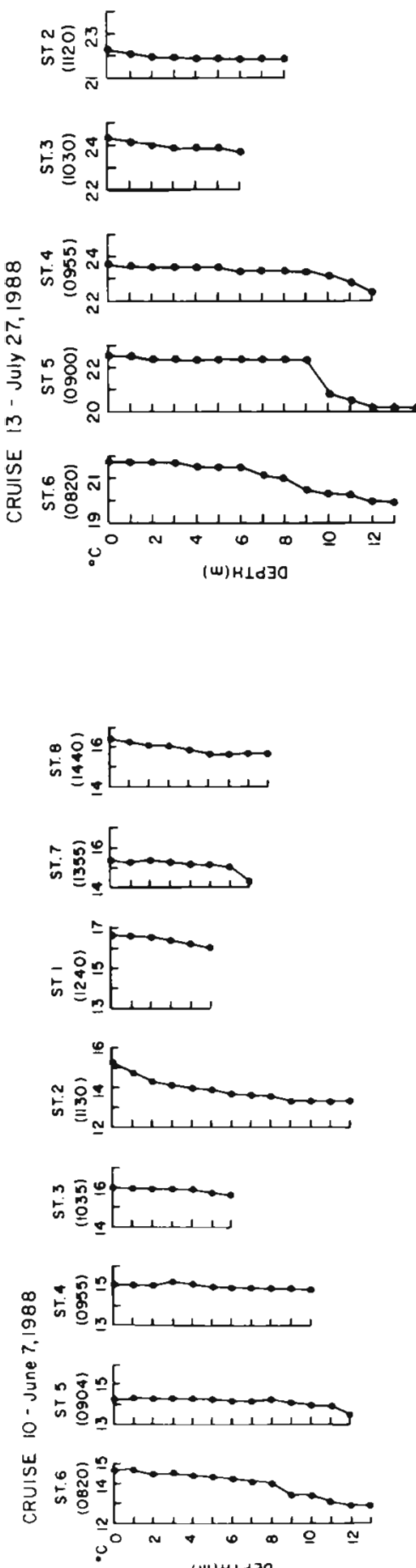

(w) H Ld 30

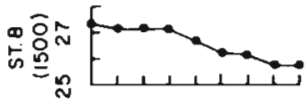

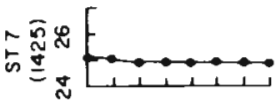
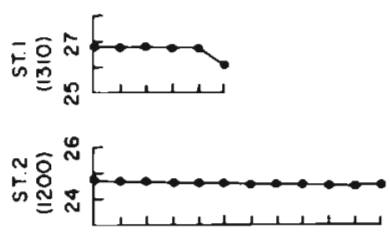

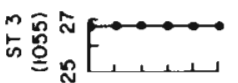
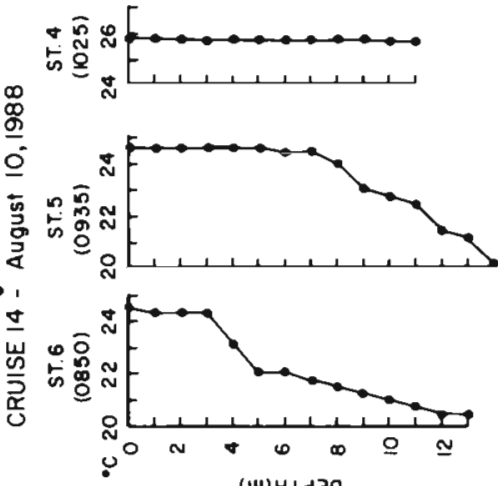

(w) HId 30
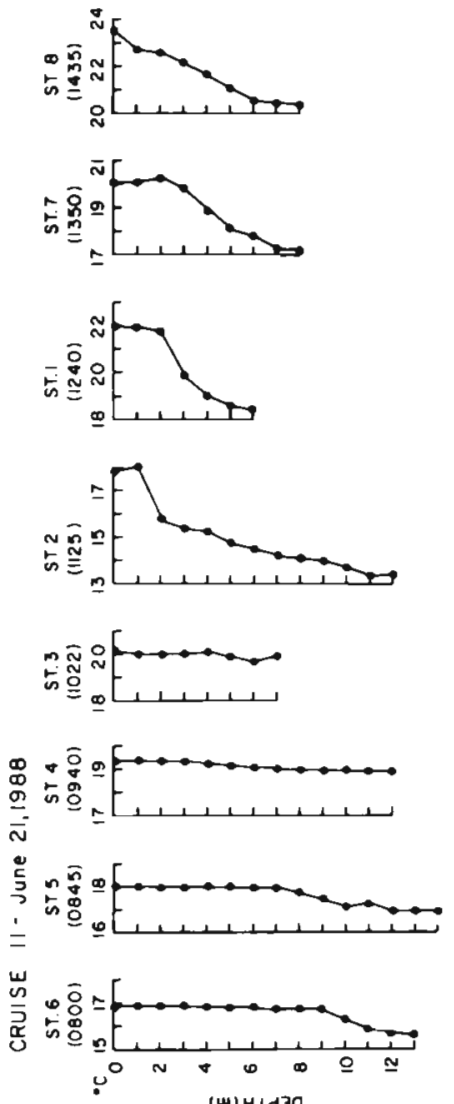

(w) H Ld 30
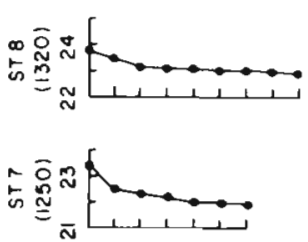

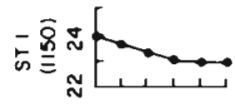
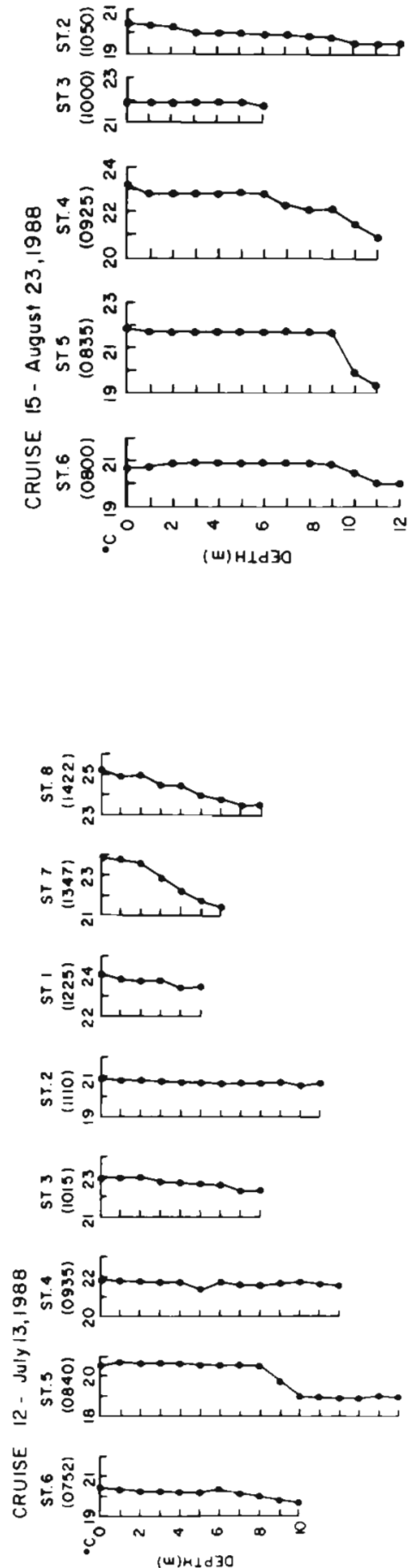


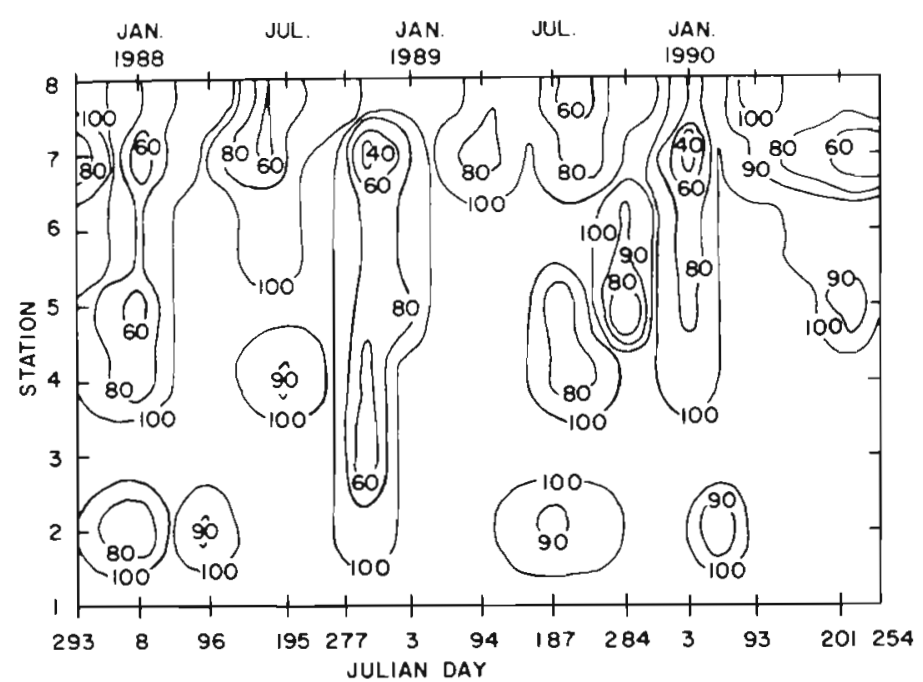

Fig. 4. Percentages of the water column in the euphotic zone $(>1 \%$ of surface light level), 20 October 1987 to 11 September $1990(n=352)$ obtained in other strongly seasonal estuarine waters (Wright \& Coffin 1983, Coffin \& Sharp 1987. Findlay et al. 1991).

Observations that bacterioplankton numbers fluctuate within the single order of magnitude of $10^{6}$ cells $\mathrm{ml}^{-1}$ have been made by numerous workers (Table 2), although few such studies have sampled over multiple annual cycles in habitats as seasonally extreme as Buzzards Bay $\left(>29^{\circ} \mathrm{C}\right.$ annual temperature range). Considering the potential of bacteria for explosive growth, the fact that bacterioplankton abundance fluctuations rarely exceed a factor of 10 might suggest predation or substrate controls on bacterioplankton abundance in the sea (Pomeroy 1974, Williams 1981, Azam et al. 1983).

The predators of bacterioplankton that are most likely of greatest importance are nano-

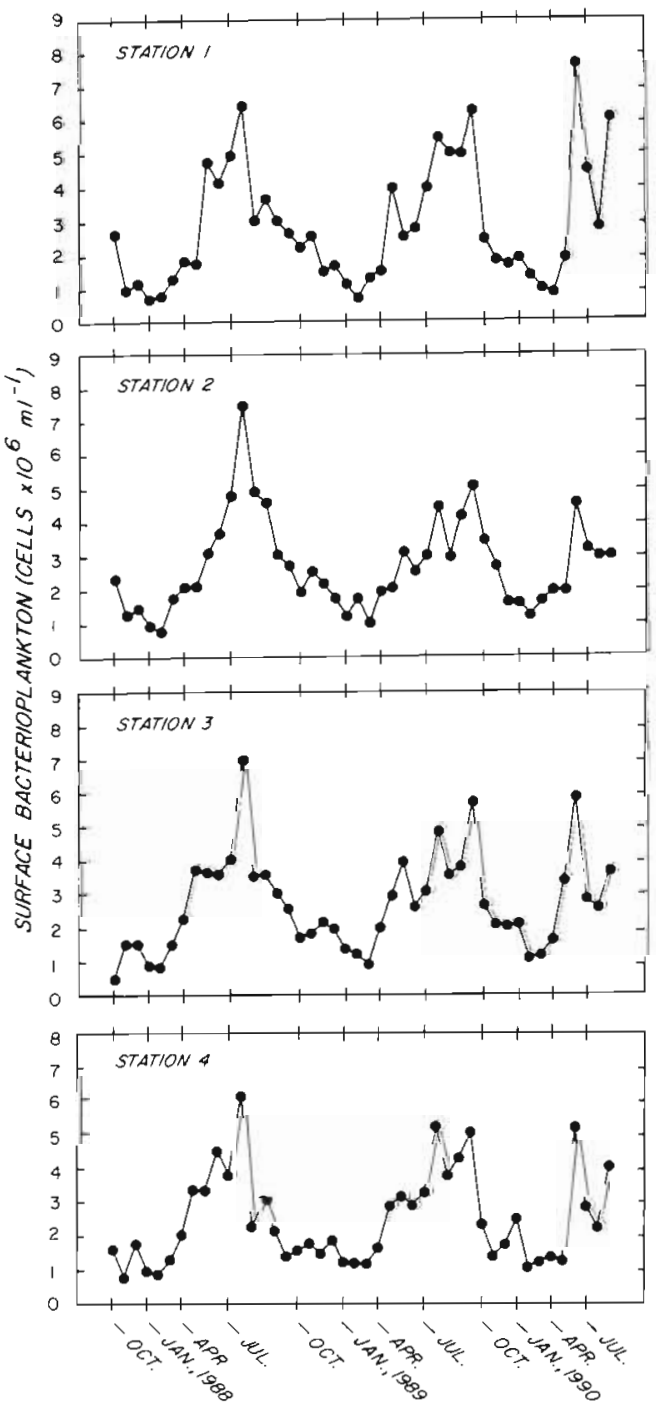

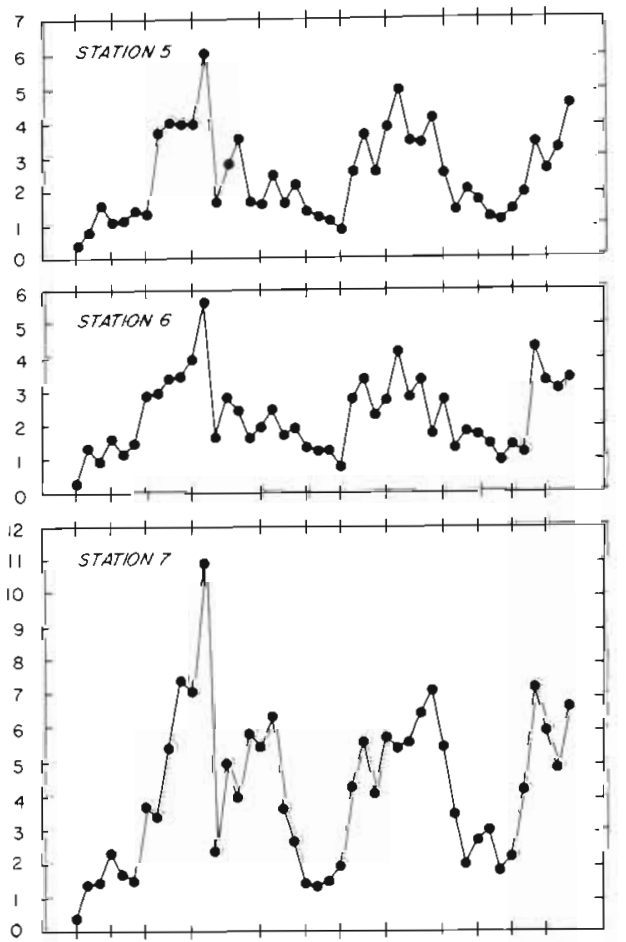

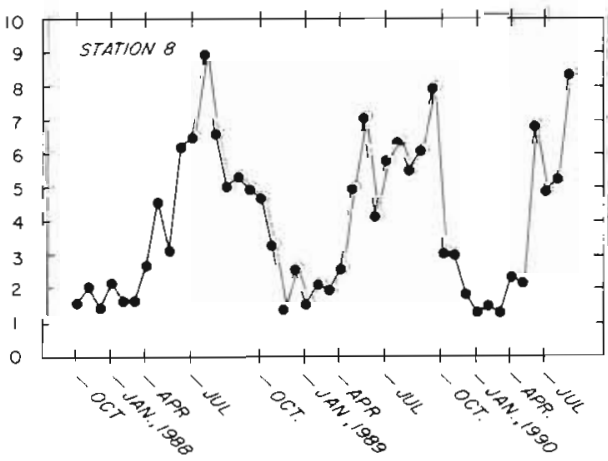

Fig. 5. Surface bacterioplankton abundance (cells $\times 10^{6} \mathrm{ml}^{-1}$ ) at each of 8 stations, 20 October 1987 to 11 September $1990(\mathrm{n}=$ 44 for each station) 


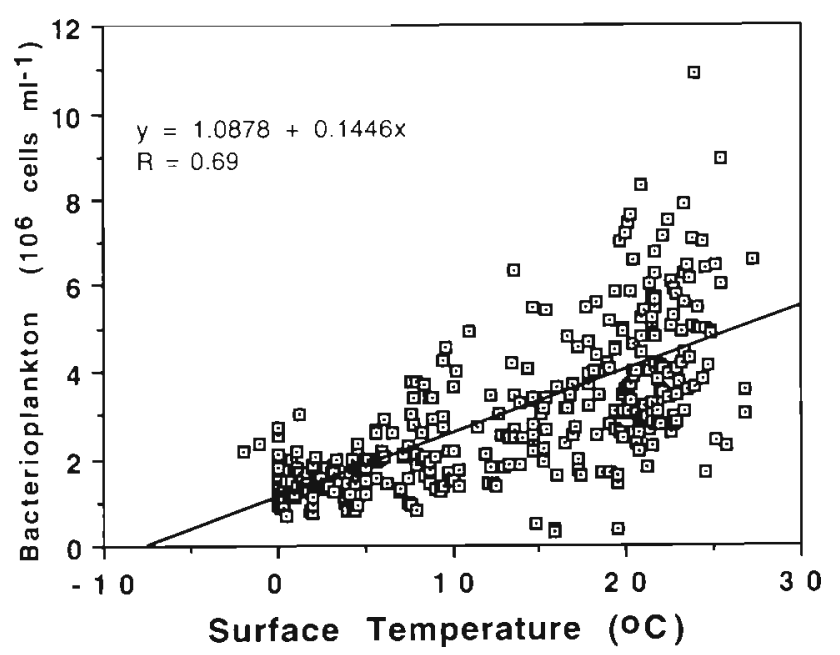

Fig. 6. Surface bacterioplankton abundance (cells $\times 10^{6} \mathrm{ml}^{-1}$ ) vs surface temperature $\left({ }^{\circ} \mathrm{C}\right), 20$ October 1987 to 11 September $1990(\mathrm{n}=352)$. The regression coefficient $(\mathrm{R})$ was not significant at the $99 \%$ confidence level

planktonic protists such as small ciliates and microflagellates (Fenchel 1988, and references therein). Thus, if predation by microprotists was a significant control on Buzzards Bay bacterioplankton abundance, we might expect to see inverse relations between their abundances. This was not the case.

Abundances of microflagellates and bacterioplankton generally paralleled each other (Fig. 7) during 1987-88, with abundances highest in summer and lowest in winter. Although these microflagellates undoubtedly included both photosynthetic and heterotrophic forms, since some chlorophyll-bearing micro-

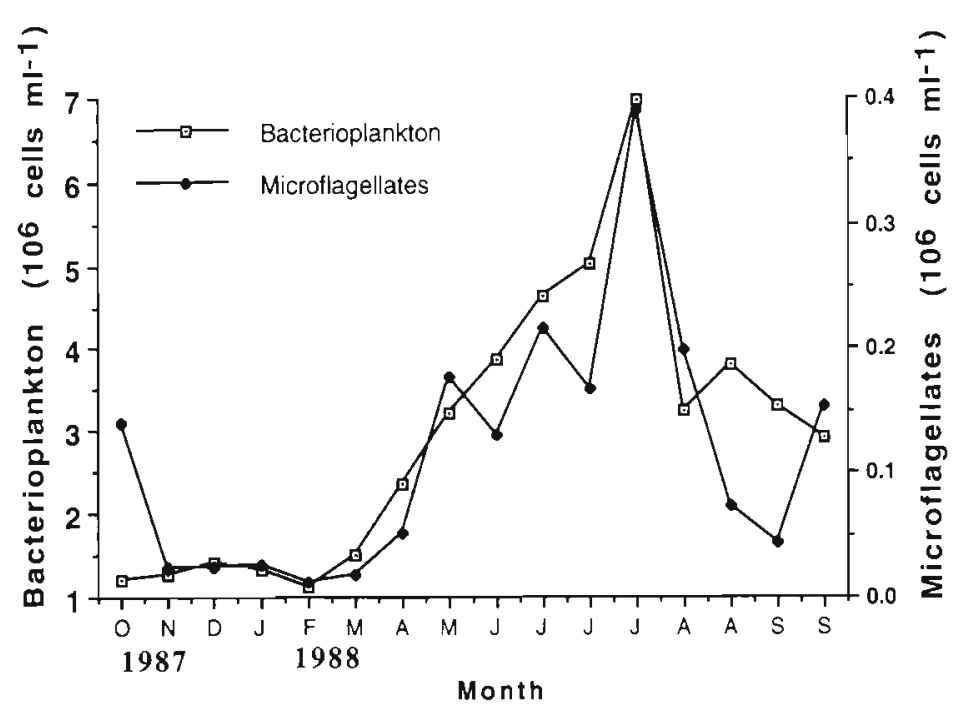

Fig. 7. Mean abundances of surface bacterioplankton (cells $\times 10^{6} \mathrm{ml}^{-1}$ ) and microflagellates (cells $\times 10^{6} 1^{-1}$ ), 20 October 1987 to 20 September 1988 ( $n=8$ for each point) flagellates have been shown to ingest bacterioplankton (Sanders \& Porter 1988, Caron et al. 1990, Sanders et al. 1990), this comparison seems reasonable. Although data on ciliates are still undergoing analyses for the October 1987 to September 1988 year of sampling (Cruises 1 to 17), aloricate ciliates, most of which are potentially bacterivorous, were most abundant in summer and least abundant in winter (R. W. Pierce pers. comm.). Thus, high and low values for bacterioplankton, their potential predators, and water temperatures paralleled each other.

We do not mean to imply that predation on bacterioplankton is unimportant. Indeed, there is considerable evidence that predation by protists is an important regulator of bacterioplankton in marine (McManus \& Fuhrman 1988, Sherr et al. 1989) and freshwater (Sanders et al. 1989) habitats. We simply wish to point out that predation is likely not the only, or possibly even primary, controller of bacterioplankton dynamics in Buzzards Bay. It is possible that in Buzzards Bay and other temperate estuarine waters, numbers of bacterioplankton would be much higher than they already are during warm periods if abundances and predation rates by protistan bacteriovores were not also concurrently high. Resolution of this question will require simultaneous measurements of bacterioplankton growth and community bacterivory, such as that of Sherr et al. (1989) from coastal waters of Georgia (USA), but extended over an annual cycle in a highly seasonal environment. To our knowledge, this has not yet been done.

Nutritional substrate levels might possibly be limiting to bacterioplankton growth, but we doubt that this is the case in Buzzards Bay. Since most of the dissolved organic matter that supports bacterioplankton originates from phytoplankton, relations between bacterioplankton and chlorophyll a levels might indicate close coupling between bacterioplankton and substrate (Linley et al. 1983, Cole et al. 1988). No clear relationships between bacterioplankton and chlorophyll a levels were found, but this is not surprising considering the generally high levels of chlorophyll a in Buzzards Bay (Borkman \& Turner 1993).

We wish to make a final point concerning bacterioplankton fluctuations. Although bac terioplankton abundance remained generally within the order of magnitude of $10^{6}$ cells $\mathrm{ml}^{-1}$, fluctuations over the annual cycle within this range were considerable. O'Brien (1985) has warned against considering environmental data numbers within the same order of magnitude to be essentially the same. By analogy, the standard 
Table 2. Bacterioplankton abundance and temperature ranges in marine and estuarine waters

\begin{tabular}{|c|c|c|c|c|c|}
\hline Location & $\begin{array}{l}\text { Sampling } \\
\text { period }\end{array}$ & $\begin{array}{l}\text { Temperature } \\
\text { range }\left({ }^{\circ} \mathrm{C}\right)\end{array}$ & $\begin{array}{l}\text { Bacteriop } \\
\text { Range }\left(10^{6} \text { cells } \mathrm{m}^{-1}\right)\end{array}$ & $\begin{array}{l}\text { ankton } \\
\text { Mean }\left(10^{6} \text { cells } \mathrm{ml}^{-1}\right)\end{array}$ & Source \\
\hline $\begin{array}{l}\text { Massachusetts } \\
\text { estuaries (USA) }\end{array}$ & $\begin{array}{l}\text { Annual } \\
\text { cycle }\end{array}$ & $-1.0-25.0$ & $0.7-7.0$ & - & Wright \& Coffin (1983) \\
\hline $\begin{array}{l}\text { Massachusetts } \\
\text { estuaries (USA) }\end{array}$ & Oct-Aug & $-1.5-27.0$ & $0.9-14.6$ & 5.6 & Wright et al. (1987) \\
\hline $\begin{array}{l}\text { Buzzards Bay } \\
\text { (USA) }\end{array}$ & $\begin{array}{l}\text { Annual } \\
\text { cycle }\end{array}$ & $-2.0-27.3$ & $0.3-10.9$ & 3.0 & Present study \\
\hline $\begin{array}{l}\text { Narragansett } \\
\text { Bay, RI (USA) }\end{array}$ & - & - & - & 2.0 & Davis \& Sieburth (1984) \\
\hline $\begin{array}{l}\text { New England } \\
\text { shelf (USA) }\end{array}$ & - & - & - & 1.0 & Davis \& Sieburth (1984) \\
\hline Sargasso Sea & - & - & - & 0.5 & Davis \& Sieburth (1984) \\
\hline $\begin{array}{l}\text { New York shelf } \\
\text { (USA) }\end{array}$ & Sep & $6.0-32.5$ & $0.2-7.6$ & 1.9 & Ferguson \& Palumbo (1979) \\
\hline $\begin{array}{l}\text { New York shelf } \\
\text { (USA) }\end{array}$ & Mar & $3.5-14.0$ & $0.7-2.0$ & - & Ducklow \& Kirchman (1983) \\
\hline $\begin{array}{l}\text { Delaware } \\
\text { estuary (USA) }\end{array}$ & $\begin{array}{l}\text { Annual } \\
\text { cycle }\end{array}$ & - & $1.0-8.0$ & & Coffin \& Sharp (1987) \\
\hline $\begin{array}{l}\text { Chesapeake } \\
\text { Bay, (USA) }\end{array}$ & Mar-Aug & - & $2.0-16.0$ & - & Jonas \& Tuttle (1990) \\
\hline $\begin{array}{l}\text { Virginia } \\
\text { estuary (USA) }\end{array}$ & Aug & $24.0-26.0$ & $1.0-8.0$ & - & Ducklow (1982) \\
\hline $\begin{array}{l}\text { North Carolina } \\
\text { estuary (USA) }\end{array}$ & Jun-Dec & $12.3-25.9$ & $1.9-18.4$ & 6.1 & Palumbo \& Ferguson (1978) \\
\hline $\begin{array}{l}\text { Georgia estuary } \\
\text { (USA) }\end{array}$ & Aug-Sep & $28.0-30.0$ & - & $5.3( \pm 0.9)$ & Sherr et al. (1989) \\
\hline $\begin{array}{l}\text { S. California } \\
\text { Bight (USA) }\end{array}$ & May & $14.5-15.5$ & $1.2-1.6$ & - & Fuhrman et al. (1985) \\
\hline $\begin{array}{l}\text { S. California } \\
\text { Bight (USA) }\end{array}$ & Oct & 19.5 & $0.8-1.2$ & - & Fuhrman et al. (1985) \\
\hline $\begin{array}{l}\text { Limfjord } \\
\text { (Denmark) }\end{array}$ & Mar-Nov & $3.0-22.0$ & $0.5-15.2$ & 6.3 & Andersen \& Sorensen (1986) \\
\hline $\begin{array}{l}\text { Bilbao coastal } \\
\text { waters (Spain) }\end{array}$ & Mar-Sep & $12.3-19.8$ & $0.32-1.28$ & - & Iribern et al. (1987) \\
\hline English Channel & Jul-Aug & - & $0.26-2.4$ & 1.3 & Linley et al. (1983) \\
\hline $\begin{array}{l}\text { Benguela } \\
\text { upwelling }\end{array}$ & Nov & - & $0.21-2.67$ & - & Linley et al. (1983) \\
\hline
\end{tabular}

of living of a human family is dramatically different depending on whether annual income is at the high or low end of $10^{4}$ dollars (or pounds, marks, etc.). Whether such differences in bacterioplankton abundance are similarly meaningful is as yet unclear.

Buzzards Bay is a highly variable estuary with pronounced short-term physical forcing super-imposed over severe seasonality. The fluctuations of hydrography and bacterioplankton presented here are matched by those of nutrients and phytoplankton pigments discussed in Borkman \& Turner (1993). Any attempt to understand or manage temperate estuaries such as Buzzards Bay requires appreciation of the intense variability of such systems.
Acknowledgements. We thank the Division of Water Pollution Control, Massachusetts Department of Environmental Protection, for funding this study (Research \& Demonstration Project 87-15), and our project managers J. Jonasch and $\mathrm{A}$. Screpetis for their continued support. We also appreciate the financial 'bridging' provided by the Center for Marine Science and Technology and the administration of University of Massachusetts, Dartmouth, (formerly Southeastern Massachusetts University) during periods of budgetary complications. Captains L. Hathaway and J. Gage provided cheerful and competent seamanship, even on days that were so miserable that if we had any sense, we would have stayed ashore. P. Verity (Skidaway Institute of Oceanography) is gratefully acknowledged for teaching bacterioplankton techniques to J.T.T Finally, we greatly appreciate the shipboard and laboratory assistance of J. Battaglia, T. C. Granata, W. Lima, L. McInnes, M. M. O'Brien, R. W. Pierce, and D. Shea. 


\section{LITERATURE CITED}

Andersen, P., Sorensen, H. M. (1986). Population dynamics and trophic coupling in pelagic microorganisms in eutrophic coastal waters. Mar. Ecol. Prog. Ser. 33: 99-109

Anraku, M. (1964). Influence of the Cape Cod Canal on the hydrography and on the copepods in Buzzards Bay and Cape Cod Bay, Massachusetts. I. Hydrography and distribution of copepods. Limnol. Oceanogr. 9: 46-60

Azam, F., Fenchel, T., Field, J. G., Meyer-Reil, L. A., Thingstad, F. (1983). The ecological role of water-column microbes in the sea. Mar. Ecol. Prog. Ser. 10: 257-263

Borkman, D. G., Turner, J. T (1993). Plankton studies in Buzzards Bay, Massachusetts, USA. II. Nutrients, chlorophyll $a$ and phaeopigments, 1987 to 1990. Mar. Ecol. Prog. Ser. 100: 27-34

Butman, C. A. (1989). Sediment-trap experiments on the importance of hydrodynamical processes in distributing settling invertebrate larvae in near-bottom waters. J. exp. mar. Biol. Ecol. 134: 37-88

Caron, D. A. (1983). Technique for enumeration of heterotrophic and phototrophic nanoplankton, using epifluorescence microscopy, and comparison with other procedures. Appl. environ. Microbiol. 46: 491-498

Caron, D. A., Porter, K. G., Sanders, R. W. (1990). Carbon, nitrogen, and phosphorus budgets for the mixotrophic phytofalgellate Poterioochromonas malhamensis (Chrysophyceae) during bacterial ingestion. Limnol. Oceanogr. 35: $433-443$

Coffin, R. B., Sharp, J. H. (1987). Microbial trophodynamics in the Delaware Estuary. Mar. Ecol. Prog. Ser. 41: 253-266

Cole, J. J., Findlay, S., Pace, M. L. (1988). Bacterial production in fresh and saltwater ecosystems: a cross-system overview. Mar. Ecol. Prog. Ser. 43:1-10

Davis, P. G., Sieburth, J. McN. (1984). Estuarine and oceanic microflagellate predation of actively growing bacteria: estimation by frequency of dividing-divided bacteria. Mar. Ecol. Prog. Ser. 19: 237-246

Ducklow, H. W. (1982). Chesapeake Bay nutrient and plankton dynamics. 1. Bacterial biomass and production during spring tidal destratification in the York River, Virginia estuary. Limnol. Oceanogr. 27: 651-659

Ducklow, H. W. Kirchman, D. L. (1983). Bacterial dynamics and distribution during a spring diatom bloom in the Hudson River plume, USA. J. Plankton Res. 5: 333-355

Ekman, S. (1953). Zoogeography of the sea. Sidgwick \& Jackson, Ltd, London

Fenchel, T. (1988). Marine plankton food chains. A. Rev. Ecol. Syst. 19: 19-38

Ferguson, R. L., Palumbo, A. V. (1979). Distribution of suspended bacteria in neritic waters south of Long Island during stratified conditions. Limnol. Oceanogr. 24. $697-705$

Findlay, S., Pace, M. L., Lints, D., Cole, J. J., Caraco, N. F., Peierls, B. (1991). Weak coupling of bacterial and algal production in a heterotrophic ecosystem. The Hudson River estuary. Limnol. Oceanogr. 36: 268-278

Fish, C. J. (1925). Seasonal distribution of the plankton of the Woods Hole region. Bull. U.S. Bur. Fish. 41: 91-179

Fuhrman, J. A., Eppley, R. W., Hagstrom, A., Azam, F. (1985). Diel variations in bacterioplankton, phytoplankton, and related parameters in the southern California Bight. Mar. Ecol. Prog. Ser. 27: 9-20

Geyer, W. R., Dragos, P. (1990). Hydrodynamic baseline measurements in New Bedford Harbor. Woods Hole Oceanographic Institution Tech. Rep WHOI-90-54, Woods Hole
Guillard, R. R. L. (1973). Division rates. In: Stein, J. R. (ed.) Phycological methods. Cambridge University Press, Cambridge, p. 289-311

Iriberri, J., Unanue, M., Barcina, 1., Egea, L. (1987). Seasonal variation in population density and heterotrophic activity of attached and free-living bacteria in coastal waters. Appl. environ. Microbiol. 53: 2308-2314

Jonas, R. B., Tuttle, J. H. (1990). Bacterioplankton and organic carbon dynamics in the lower mesohaline Chesapeake Bay. Appl. environ. Microbiol. 56: 747-757

Lillick, L. C. (1937). Seasonal studies of the phytoplankton off Woods Hole, Massachusetts. Biol. Bull. 73: 488-503

Linley, E. A. S., Newell, R. C., Lucas, M. I. (1983). Quantitative relationships between phytoplankton, bacteria and heterotrophic microflagellates in shelf waters. Mar Ecol. Prog. Ser. 12: 77-89

Marcus, N. H. (1984). Recruitment of copepod nauplii into the plankton: importance of diapause eggs and benthic processes. Mar. Ecol. Prog. Ser. 15: 47-54

Marcus, N. H., Fuller, C. M. (1989). Distribution and abundance of eggs of Labidocera aestiva (Copepoda: Calanoida) in the bottom sediments of Buzzards Bay, Massachusetts, USA. Mar. Biol. 100: 319-326

McManus, G. B., Fuhrman, J. A. (1988). Control of marine bacterioplankton populations: measurement and significance of grazing. Hydrobiologia 159: 51-62

NOAA/EPA (1989). Susceptibility of east coast estuaries to nutrient discharges: Passamaquoddy Bay to Chesapeake Bay. Strategic assessment of near coastal waters, summary report. U.S. National Oceanic and Atmospheric Administration/U.S. Environmental Protection Agency, Washington, DC

O'Brien, W. J. (1985). Importance of perspective in limnology. In: Likens, G. E. (ed.) An ecosystem approach to aquatic ecology. Mirror Lake and its environment. SpringerVerlag, Berlin, p. 84-88

Palumbo, A. V., Ferguson, R. L. (1978). Distribution of suspended bacteria in the Newport River Estuary, North Carolina. Estuar. Coast. Mar. Sci. 7: 521-529

Peck, J. I. (1896). The source of marine food. Bull. U.S. Bur Fish. 15: $351-368$

Pomeroy, L. R. (1974). The ocean's food web, a changing paradigm. BioScience 24: 499-504

Porter, K. G., Feig, Y S. (1980). The use of DAPI for identifying and counting aquatic microflora. Limnol. Oceanogr. 25: $943-948$

Pruell, R. J., Norwood, C. B., Bowen, R. D., Boothman, W. S., Rogerson, P. F., Hackett, M., Butterworth, B. C. (1990). Geochemical study of sediment contamination in New Bedford Harbor, Massachusetts. Mar. environ. Res. 29: 77-101

Rhoads, D. C., Tenore, K., Browne, M. (1975). The role of resuspended bottom mud in nutrient cycles of shallow embayments. In: Cronin, L. E. (ed.) Estuarine research, Vol. I, Chemistry, biology, and the estuarine system. Academic Press, New York, p. 563-579

Rhoads, D. C., Young, D. K. (1970). The influence of depositfeeding organisms on sediment stability and community trophic structure. J. mar. Res. 28: 150-178

Roman, M. R. (1978). Tidal resuspension in Buzzards Bay, Massachusetts. Il. Seasonal changes in the size distribution of chlorophyll, particulate concentration, carbon and nitrogen in resuspended particulate matter. Estuar. coast. mar. Sci. 6: 47-53

Roman, M. R. (1980). Tidal resuspension in Buzzards Bay, Massachusetts. III. Seasonal changes of nitrogen and carbon:nitrogen ratios in seston and zooplankton. Estuar. coast. mar. Sci. 11: $9-16$ 
Roman, M. R., Tenore, K. R. (1978). Tidal resuspension in Buzzards Bay, Massachusetts. I. Seasonal changes in the resuspension of organic carbon and chlorophyll a. Estuar. coast. mar. Sci. 6: 37-46

Sanders, H. L. (1958). Benthic studies in Buzzards Bay. I. Animal-sediment relationships. Limnol. Oceanogr. 3: $245-258$

Sanders, H. L. (1960). Benthic studies in Buzzards Bay. III. The structure of the soft-bottom community. Limnol. Oceanogr. 5: 138-153

Sanders, H. L., Grassle, J. F., Hampson, G. R., Morse, L. S., Garner-Price, S., Jones, C. C. (1980). Anatomy of an oil spill: long-term effects from the grounding of the barge Florida off West Falmouth, Massachusetts. J. mar. Res. 38: $265-380$

Sanders, R. W., Porter, K. G. (1988). Phagotrophic phytoflagellates. In: Marshall, K. C. (ed.) Advances in microbial ecology, Vol. 10. Plenum, New York, p. 167-192

Sanders, R. W., Porter, K. G, Bennett, S. J., DeBiase, A. E. (1989). Seasonal patterns of bacterivory by flagellates, ciliates, rotifers, and cladocerans in a freshwater planktonic community. Limnol. Oceanogr. 34: 673-687

Sanders, R. W. Porter, K. G., Caron, D. A. (1990). Relationship between phototrophy and phagotrophy in the mixotrophic chrysophyte Poterioochromonas malhamensis. Microb. Ecol. 19: 97-109

Sherr, B. F., Sherr, E. B., Pedros-Alio, C. (1989). Simultaneous measurement of bacterioplankton production and protozoan bacterivory in estuarine water. Mar. Ecol. Prog. Ser. 54: $209-219$

Signell, R. P. (1987). Tide- and wind-forced currents in Buzzards Bay, Massachusetts. Woods Hole Oceanographic. Institution. Tech. Rep WHOI-87-15, Woods Hole

This article was presented by $R$. Williams, Plymouth, UK
Smayda, T. J. (1989). Assessment of primary productivity and eutrophication potential in New Bedford Outer Harbor in response to nutrient regime and potential inputs. Final report submitted to Camp, Dresser \& McKee, Inc., Boston, MA

Stenner, T. W., Gulbransen, T C., Baptiste, E. M. (1988). Water quality assessment for Buzzards Bay, Massachusetts. Final report to Massachusetts Executive Office of Environmental Affairs. Battelle Ocean Sciences, Duxbury, MA

Sumner, F. B., Osburn, R. C., Cole, L. J., Davis, B. M. (1913). A biological survey of the waters of Woods Hole and vicinity. Bull. U.S. Bur. Fish, Part 1, 31:734

Valiela, I., Costa, J. E. (1988). Eutrophication of Buttermilk Bay, a Cape Cod coastal embayment: concentrations of nutrients and watershed nutrient budgets. Environ. Mgmt 12: $539-553$

Wieser, W. (1960). Benthic studies in Buzzards Bay. II. The meiofauna. Limnol. Oceanogr. 5: 121-137

Williams, P. J. leB. (1981). Incorporation of microheterotrophic processes into the classical paradigm of the planktonic food web. Kieler Meeresforsch., Sonderh. 5: 1-28

Wright, R. T., Coffin, R. B. (1983). Planktonic bacteria in estuaries and coastal waters of northern Massachusetts spatial and temporal distribution. Mar. Ecol. Prog. Ser. 11: $205-216$

Wright, R. T., Coffin, R. B., Lebo, M. E. (1987). Dynamics of planktonic bacteria and heterotrophic microflagellates in the Parker Estuary, northern Massachusetts. Contin. Shelf Res. 7: 1383-1397

Young, D. K. (1971). Effects of infauna on the sediment and seston of of a subtidal environment. Vie Milieu, Suppl. 22: $557-571$

Manuscript first received: October 26, 1993

Revised version accepted: June 14, 1993 